\title{
Assessment of Human Perception on the Impact of Climate Change and Population Growth on Water Scarcity in Katsina Urban Area, Katsina State, Nigeria
}

\author{
*Mudassir Hassan ${ }^{1}$, Abdulmalik Sada Maiwada \\ ${ }^{1,2}$ Department of Geography, \\ Umaru Musa Yar'adua University, \\ P. M. B 2218, \\ Katsina, Nigeria.
}

Email:mudassirhk3@gmail.com

\begin{abstract}
Water is part of the global resources facing a great threat from the current changing climate and population increase, its scarcity and dramatic decrease in Arid and semi-arid regions of the world implies a setback to socio-economic development. This study examines the impact of climate change and population increased on water scarcity in urban Katsina through human perception. A purposive sampling method was employed and a total of 245 questionnaires were administered to the household heads in the study area. Descriptive statistics of frequency distribution and percentage were used in the analysis of the collected data. The results revealed that majority (70.2\%) of the respondents are aware of the changing climate and its impact on water resource. Changes in the volume of water resources over years in the study area was significantly decreased (well 67.6\%, tap $72.5 \%$ and rainwater $47.3 \%$ ) which resulted in scarcity as perceived by the respondents. Majority (53.8\%) have no idea about the changes in volume of boreholes water. The most significant impacts of climate change on water resource in the study area were low rainfall duration and intensity, drying up of wells, lowering of water table and increase frequency and occurrence of drought. It is recommended that water resource supply infrastructures, integrated water resource management and creation of awareness on the impacts of climate change on water should be provided as part of the strategies to ameliorate the impact of climate change on water resources.
\end{abstract}

Keywords: Climate change; Perception; Population Growth; Urban Katsina; Water scarcity.

\section{INTRODUCTION}

World water resources are already facing dramatic changes as a result of climate change, high water demands, population growth, industrialization and urbanization (Alfano, et al., 2015). In many arid and semiarid regions of the world, water resources have become a critical element for socioeconomic development. Rapid population growth and economic development, water resources in most developing countries faces severe pressure from human intervention, further triggering water scarcity issues. Water scarcity impedes development of many kinds, provokes food shortages and conflicts that exerts adverse effects on human and ecosystem health; thus, water provision is an important ecosystem service, which is a key issue in the river basin management to reconcile water availability and demand (Notter, et al., 2011; Zhihui, et al., 2015).

*Author for Correspondence

Hassan M., Maiwada A. S., DUJOPAS 7 (3a): 77-83, 2021 
Climate change as a result of both natural factors and human activities is altering the earth's hydrologic cycles to various degrees. Climate change affects hydrology mainly through changes in precipitation, temperature, and evaporation (Dong, et al., 2012; Tianhong and Yuan, 2015). Both human population and water resources are unevenly distributed worldwide. In many areas, densely populated regions do not overlap with those that are water rich. Due to the rapidly increasing population and water use per capita in many areas of the world, around one third of the world's population currently lives under physical water scarcity (Oki, and Kanae, 2006). The physical water scarcity (or water resources scarcity is not, however, the only scarcity that human populations face. A community or a section of it, can also face water scarcity induced by political power, policies, and/or socioeconomic relations, called social water scarcity (or second order water scarcity) (Ohlsson, and Turton,1999). For example, the 2006 Human Development Report, concludes that water scarcity is not rooted in the physical availability of water, but in unbalanced power relations, poverty, and inequality (Kummu, 2010).

Many previous studies have focused on assessing the global water scarcity from various disciplines (e.g. Oki, and Kanae, 2006; Kummu, 2010; Islam, et al., 2007; Haddeland, et al., 2014). The majority of these studies have addressed how physical water scarcity may develop over time into the future, with a time span of a few decades ahead. The results have revealed a rapid increase in the number of people under water stress or water shortage as a result of increasing population and/or water use, and in some cases as a result of climatic change (e.g. Oki, and Kanae, 2006). Despite the effort made by numerous researchers on water scarcity studies, less attention has been made in assessing water scarcity in urban Katsina over the years until the present day. Therefore, this study aimed at assessing human perception on the impact of climate change and population increase on water scarcity. The insights gained in this study will help us to understand the dynamics and relative impacts of changes in population and water resources availability on water shortage.

\section{MATERIALS AND METHOD}

\section{Study Area}

The study area encompasses the entire urban Katsina of approximately 3,370 $\mathrm{km}^{2}$ (Figure 1), It is located between $11^{0} 08^{\prime} \mathrm{N}$ to $13^{02} 2^{\prime} \mathrm{N}$ latitude and $6^{0} 52^{\prime} \mathrm{E}$ to $9^{0} 20^{\prime} \mathrm{E}$ longitudes (Maiwada, 2017). It belongs to the tropical continental (wet and dry) climatic zone of northern Nigeria. It is characterized by short wet and long dry seasons, with very high annual temperature range (Hazo, et al., 2019). The study area receives few months of annual rainfall normally between June and October, having an annual average of about 70cm (Maiwada, 2017; Abaje, et al., 2014). Ruma, and Sheikh, (2010) affirmed that temperature of the area is high in almost all part of the year because of its position in the tropical region, with maximum temperature of about $38^{\circ} \mathrm{C}$ or higher recorded in the second quarter of the year and the minimum day temperature of about $22^{\circ} \mathrm{C}$ or lower in the late fourth quarter and the beginning of the first quarter of the year. The study area recorded lower relative humidity in the months of February ranges between $20-25 \%$ that is when the atmosphere is most dry compared to its higher value of $70-80 \%$ in August/September when the highest amount of rainfall is received during the year (Ruma, and Inkani, 2012).

The study area compose of Sudan Savannah vegetation. The major land use in the area are residential and to some extent irrigation farming along river Ginzo. Other occupations include trading, as well as civil servants. The study area has a population of 318,132 people 
(National population commission 2006 census). This population figure has further being projected to be 450,548 in the year 2018 with an annual growth rate is $2.9 \%$ (NPC, 2006).

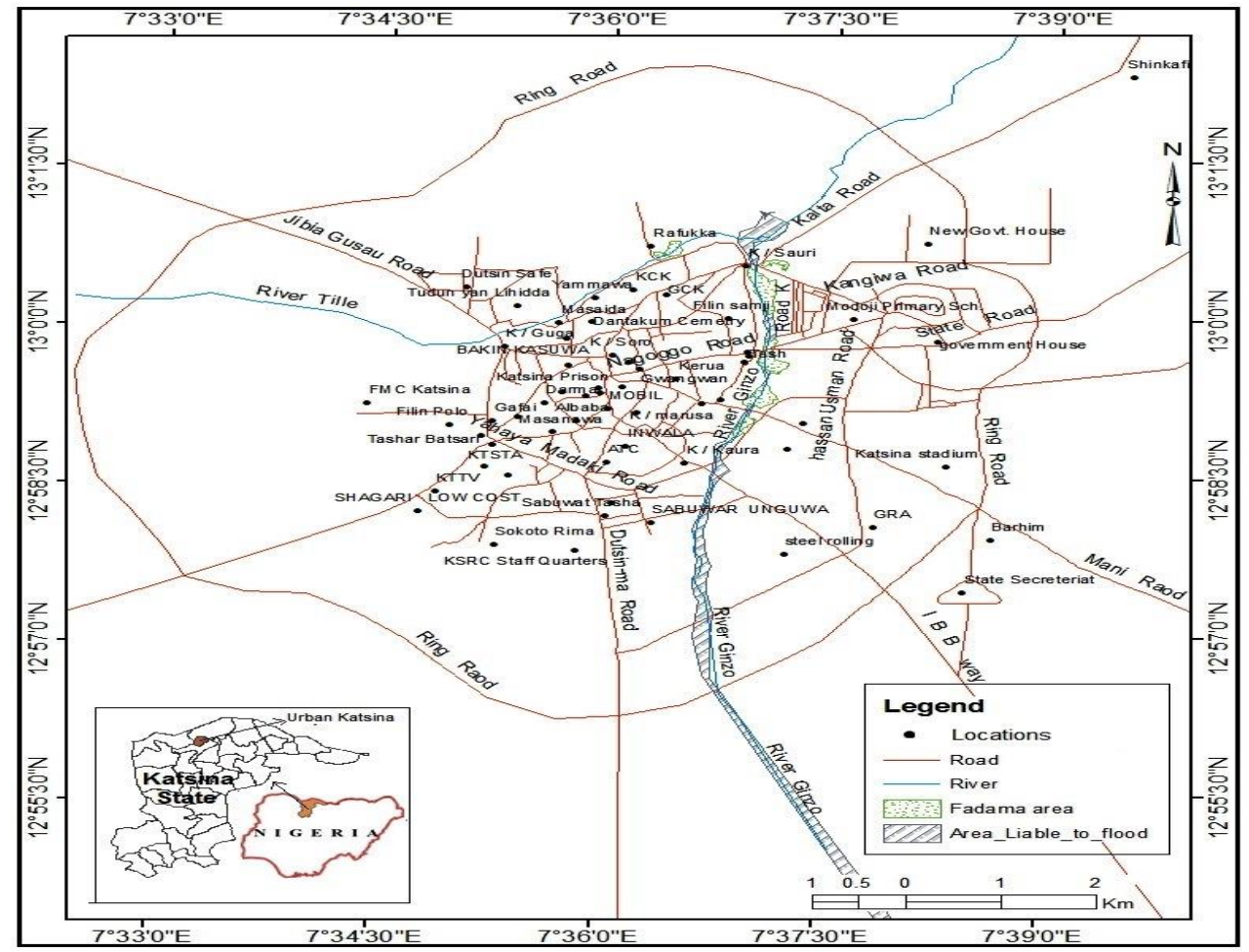

Figure 1: Map of the study area. Source: Cartography Lab, UMYU Katsina

\section{Methods}

In this study, data and information were obtained from a field study based on the results of 250 questionnaires administered to household heads in Katsina urban area in May 2019. A total of 50 questionnaires were administered to each of the 5 communities in the area namely: Tudun matawalle, Rafin dadi, Kwado, Shaiskawa and Kofar Marusa. The questionnaires were purposively administered to household heads and must have been residing in the area for at least two years and above. The basis for this was to gather information from respondents who have had experiences on impacts of climate change and population growth on water resources over the years and are more concerned and conscious about the imminent impacts of these changes on water resources. The respondent were asked to assess their knowledge and understanding about climate change issues, population growth and water resources through answering 17 multiple choice questions on a variety of climate and water resource related issues. Multiple possible choices were given for each question. Simple descriptive statistics such as mean, percentage and frequency distribution were used in this study.

\section{RESULTS AND DISCUSSION}

The size of the household is presented in Table 1. It indicates that, majority of the respondents $(52.2 \%)$ are between the range of $6-10$ per house. Followed by $(22.9 \%)$ which ranges between $0-5$, the least household size ranges above 21 persons with $3.3 \%$. The result further indicate that about $90.2 \%$ are range between $1-15$ persons in the study area. This is in line with the findings of (Abaje, et al., 2014) in their study on climate variability and change, impacts and adaptation strategies in Dutsin-ma local government area of Katsina state, Nigeria. 
Table 1: No of persons in the household

\begin{tabular}{ccc}
\hline & Frequency & Percentage \\
\hline$\leq 5$ & 56 & 22.9 \\
$6-10$ & 128 & 52.2 \\
$11-15$ & 37 & 15.1 \\
$16-20$ & 16 & 6.5 \\
$\geq 21$ & 8 & 3.3 \\
Total & 245 & 100 \\
\hline
\end{tabular}

Source: Field survey, 2019

Table 2 presents the awareness of climate change effect on water resources. The result revealed that majority of the respondents $(70.2 \%)$ opined that they are aware climate change is affecting water resources, while the remaining $29.8 \%$ claimed that they are not aware. This is due to the fact that majority of the respondents observed the changes of the water resources. This result is in line with the findings of Anwar (2009); Oyebande, and Odunuga, (2010), who assessed the impact of climate change on water resources.

Table 2: Awareness of climate change effect on water resources

\begin{tabular}{cccc}
\hline S/No & Awareness & Frequency & Percentage \\
\hline 1 & Aware & 172 & 70.2 \\
2 & Not aware & 73 & 29.8 \\
& Total & 245 & 100 \\
\hline
\end{tabular}

Source: Field survey, 2019

Table 3 presents the result on main sources of water among the respondents. These include well within home, public wells, tap within home, public tap, borehole, rainwater and water vendors. It revealed that majority $(38 \%)$ of the respondents claimed that well within home is their main source of water, $31.8 \%$ had water vendors as their main source, $22.9 \%$ said boreholes are their main source, public well 3.3\%, tap within home $2.4 \%$ and only $0.8 \%$ opined other sources such as public tap and rainwater respectively. A closer examination of this result revealed that an aggregate of $73.1 \%$ of the respondents relied on a relatively wells and water vendors as the major sources of water. This finding is in agreement with that of Ebere, (2012); UNEP (2005); De Wit, (2006) where the researchers found out that well within home, surface water supplies, groundwater was the major source of water of their study area.

Table 3: Perceived main source of water among the respondents

\begin{tabular}{cccc}
\hline S/No & Variables & Frequency & Percentage \\
\hline 1 & Well within home & 93 & 38 \\
2 & Public wells & 8 & 3.3 \\
3 & Tap within home & 6 & 2.4 \\
4 & Public tap & 2 & 0.8 \\
5 & Bore hole & 56 & 22.9 \\
6 & Rain water & 2 & 0.8 \\
7 & Water vendors & 78 & 31.8 \\
& Total & 245 & 100 \\
\hline
\end{tabular}

Source: Field survey, 2019

Perceived result of changes in the volume of water resource was presented in table 4 . The result revealed that majority of the respondents $(67.6 \%)$ believed that well water was decreasing, 72.5\% opined that water supply from tap was decreasing, $47.3 \%$ believed that rain water was also decreasing. Majority (53.8\%) of the respondents about borehole water stated that they had no idea about the changes. This result is generally indicating that the volume of water is decreasing in the study area as perceived by the majority of the 
respondents. This findings is in agreement with that of Ebere, (2012) where the researcher found out that majority of the respondents believed that the volume of water was decreasing in the last thirty years.

Table 4: Perceived changes in volume of water resources over years.

\begin{tabular}{lcccc}
\hline & Wells (\%) & Taps (\%) & Rain water (\%) & Boreholes (\%) \\
\hline No change & 9.7 & 6.3 & 26.4 & 19 \\
Increased & 4.2 & 4.7 & 13.8 & 9.7 \\
Decreased & 67.6 & 72.5 & 47.3 & 17.5 \\
No idea & 18.5 & 16.5 & 12.5 & 53.8 \\
\hline
\end{tabular}

Source: Field survey, 2019

The perceived impacts of climate change on water resource among the respondents was presented in Table 5. The result revealed that, the most significant perceived impact of climate change on water resources among the respondents was low rainfall intensity with the majority of $(39.6 \%)$. This findings is in line with the projection by UCS (2011) that, many Sub-Saharan Africa countries would face water shortage from now on. Decrease in groundwater level accounted for $15.9 \%$. This is in agreement with findings of Al-Gamal, et al., (2009), the researcher found out that climate change is likely to impact groundwater resources, either directly, via changing precipitation patterns, or indirectly through the interaction of changing precipitation patterns with changing land-use practices and water demand. Drying up of wells had 14.3\%, higher water temperature accounted for $9.8 \%$, increase in frequency of drought had 6.9\%, increase in groundwater level possess 3.3\%, lower water temperature and high rainfall intensity accounted for 2.1 and $2.1 \%$ and the remaining variables such as improve the quality of groundwater, shrinking of surface water, more intense and frequent heat waves and salinization of groundwater had $1.6 \%$ and $1.2 \%$ respectively. These findings are in line with UNFCCC, (2006) assertion that presently, water availability is decreasing in Africa with differences between the location and need for water resources. Anwar, et al., (2009); Ebere, (2012) also stated that reduction in water quantity will lead to reduction in water quality and associated impacts on health and biodiversity.

Table 5: Perceived impact of climate change on water resources

\begin{tabular}{clcc}
\hline S/ & \multicolumn{1}{c}{ Variables } & Freq & Per \\
\hline 1 & High rainfall intensity & 5 & 2.1 \\
2 & Low rainfall intensity & 97 & 39.6 \\
3 & Higher water temperature & 24 & 9.8 \\
4 & Lower water temperature & 5 & 2.1 \\
5 & Salinization of groundwater & 3 & 1.2 \\
6 & Improve the quality of groundwater & 4 & 1.6 \\
7 & Increase in groundwater level & 8 & 3.3 \\
8 & Lowering in groundwater level & 39 & 15.9 \\
9 & Shrinking of surface water & 4 & 1.6 \\
10 & Drying up of wells & 35 & 14.3 \\
11 & Increase in frequency of drought & 17 & 6.9 \\
12 & More intense and frequent heat waves & 4 & 1.6 \\
& & 245 & 100 \\
\hline
\end{tabular}

Source: Field survey, 2019

\section{CONCLUSION}

The study tried to examine people's perception on climate change impact and population increase on water scarcity. As the population of Katsina urban area is increasing, there is high tendency of high water demand in order to satisfy our basic today to today needs and 
desires. This water might becoming very scarce and at a high financial and ecological price. The result obtained is quite important in addressing the impact of population increase and changing climate on water resource as perceived by many respondents. Planning for the future should account for the possible impact of climate change on water resources availability, the population growth and the societal needs in order to meet the desire for multiple structures It is recommended that water resource supply infrastructures, integrated water resource management and creation of awareness on the impacts of climate change on water should be provided as part of the strategies to ameliorate the impact of climate change on water resources.

\section{REFERENCES}

Abaje, I. B., Sawa B. A \& Ati O. F (2014) Climate variability and change, impacts and adaptation strategies in Dutsin-ma local government area of Katsina state, Nigeria. Journal of Geography and Geology, 6(2), 103 - 112.

Alfano, M., Brockley, S., Muir, M.A., Areikat, S. and Gracy, M., 2015, August. Water scarcity and drought management plans as enabling elements for achieving the SDGs in West Asia and North Africa. In International Conference on Sustainable Development. http://icsd. org/wpcontent/uploads/sites/4/2016/06/ICSD_Paper_Alfano_Brockley_Muir_Areikat_Gracy_Aug2 015. pdf.

Anwar A. S., Sokona, Y., \& Dodo, A. K. (2009). Climatic changes and groundwater resources in Africa. International Journal of Climate Change Strategies and Management, 1(2), 133145.

Al-Gamal, S. A., Sokona, Y., \& Dodo, A. K. (2009). Climatic changes and groundwater resources in Africa. International Journal of Climate Change Strategies and Management.

De Wit, M. (2006). The perception of and adaptation to climate change in Africa. CEEPA Discussion Paper No.10. University of Pretoria.

Dong, L.H., Xiong, L.H., Yu, K.X., Li, S. (2012) Research advances in effects of climate change and human activities on hydrology. Adv. Water Sci. 2, 278-285.

Ebere, N. C. (2012) Effect of climate change on household water resources in Benue state, Nigeria. Msc. Dissertation submitted to the department of agricultural extension, university of Nigeria, Nsukka.

Haddeland I., Heinke J., Biemansd H., Eisnere S., Flörkee, M., Hanasakif, N., Konzmannb, M., Ludwigd, F., Masakif, Y., Scheweb, J., Stackeg, T., Tesslerh, Z.D., Wadai, Y. \& Wisser, D (2014) Global water resources affected by human interventions and climate change. PNAS, 111(9), 3251-3256

Hazo, A. I., Sawa, B. A. and Mamman, M., (2019) Assessment of climate change awareness and risk perception among rural people in Funtua local government Area, Katsina State, Nigeria. International of trend in scientific research and development, 3 (2), 2937

Islam S, Oki T, Kanae S, Hanasaki N, Agata Y and Yoshimura K (2007) A grid-based assessment of global water scarcity including virtual water trading Water Resour. Manage. 21, 19-33

Kummu, M, Ward, P.J., Moel, H and Varis O (2010) Is physical water scarcity a new phenomenon? Global assessment of water shortage over the last two millennia, Environ. Res. Lett. 5, 1-10

Maiwada, A. S. (2017) People's response to climatic variability awareness and observed changes in three selected population densities of Katsina urban area, Nigeria. International Journal of Science and Research, 6(6), 1566-1572 
National Population Commission (2006) Population Distribution by Age and Sex. State and Local Government Area; Priority Table Volume IV.

Notter, B.; Hurni, H.; Wiesmann, U.; Abbaspour, K. (2011) Modelling water provision as an ecosystem service in a large east African River Basin. Hydrol. Earth Syst. Sci. 8, 79878033.

Ohlsson, L., and Turton A. R. (1999) The turning of a screw: Social resource scarcity as a bottleneck in adaptation to water scarcity. Occasional Paper Series, School of Oriental and African Studies Water Study Group, University of London.

Oki, T. and Kanae, S. (2006) Global hydrological cycles and world water resources Science 313, 1068-72

Oyebande, L., and Odunuga, S. (2010). Climate change impact on water resources at the transboundary level in West Africa: the cases of the Senegal, Niger and Volta Basins. Open Hydrology Journal, 4(1), 163-172

Ruma, M. M. and Sheikh, A. U. (2010) Reuse of wastewater in urban farming and urban planning implications in Katsina metropolis, Nigeria. African Journal of Environmental Science and Technology, 4(1), 28-33

Ruma, M. M. and Inkani A. I. (2012) People's adaptation to potable water scarcity in Katsina urban area, Katsina state, Nigeria. Journal of natural and applied sciences, 3(1), 1 Sept, 2012

Tianhong, L. and Yuan, G. (2015) Runoff and sediment yield variations in response to precipitation changes: A Case Study of Xichuan Watershed in the Loess Plateau, China. Water, 7, 5638-5656

United Nations Environmental Protection (UNEP) (2005). Africa environment outlook: past, present and future perspectives. United Nations Environment programme available at: www.unep.org/dewa/Africa/ publications/AEO-1/164.htm

United Nations Framework Convention on Climate Change (UNFCCC) (2006). Background paper on impacts, vulnerability and adaptation to climate change in Africa for Decision 1cp.10 of the UNFCCC convention Accra, Ghana, 21 -23 September, 2006

Zhihui, L., Xiangzheng, D., Feng, W. and Shaikh S.H. (2015) Scenario Analysis for water resources in response to land use change in the middle and upper reaches of the Heihe River Basin. Sustainability, 7, 3086-3108 